SD
566 Q.L.S.H.E Representatives

Conslidation - cattan -rest candes

asimints 


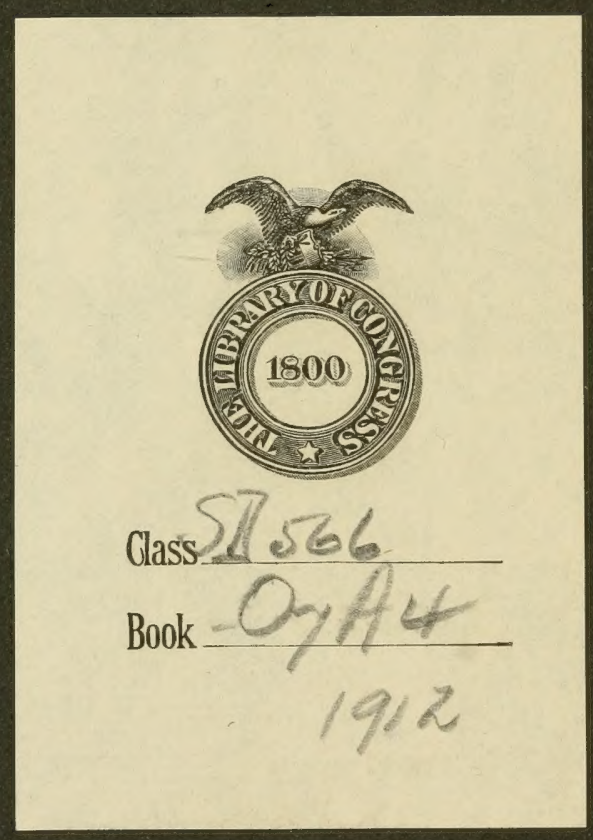




\section{CONSOLIDATION OF CERTAIN FOREST LANDS}

\section{HEARINGS}

BEFORE

\section{THE COMMITTEE ON THE PUBLIC LANDS}

HOUSE OF REPRESENTATIVES

ON

SENATE BILL 4745

FEBRUARY 28 AND 29, 1912

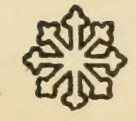




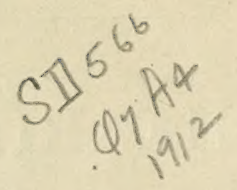

ก. ลี ก.

APR 201912

$\because \vdots$ 


\title{
CONSOLIDATION OF CERTAIN FOREST LANDS.
}

\author{
Committee on the Public Lands, \\ House of Representatives, \\ February 28, $1912-11$ a. $m$.
}

The committee this day met, Hon. James M. Graham (acting chairman) presiding.

The CHAIRMan. Is the subcommittee ready to report Senate bill 4745 ?

Mr. TAYlor. Mr. Dent is chairman of that subcommittee, and it was reported at our last meeting on Monday. At that meeting some of the members that were not members of the subcommittee desired to have some further information about it, and more particularly Mr. Raker, who lives near there; so we deferred further action on it until to-day, leaving that as unfinished business to take up this morning. Mr. Hawley is here, and Mr. Potter is here, pursuant to our request for them to furnish this additional information, and I presume they are here for explanation or cross-examination by either the gentleman from California or from Iowa, or other members of the committee.

The Chamman. Will you indicate what the specific information is, first?

Mr. RAKER. We would like to consider the bill offered by Mr. Hawley.

\section{STATEMENT OF WILLIS C. HAWLEY.}

Mr. Hawley. Mr. Chairman and gentlemen, through the Paulina National Forest, in Oregon, there runs a body of land which formerly belonged to an old wagon-road company. Another company, the Oregon Land Corporation, has recently acquired a part of these lands. The lands acquired by the company run down through the national forest, taking in every odd-numbered section. The company has filed on water rights under the laws of the State of Oregon for the purpose of irrigating these lands, which will be valuable lands when irrigated. The Southern Pacific Railroad is building an extension, which will be its main line, we understand, between San Francisco and Portland, and it will run through these lands. The lands that the company wish to exchange are in the northern part of the forest and are covered with yellow pine. The lands they wish to acquire are in the southern part of the forest and are covered with jack pine. The yellow pine is very valuable pine and the jack pine is of little value.

Mr. Volstead. I understood it was pole pine. What is the difference between pole pine and jack pine?

Mr. HAwLEY. I don't think there is any difference. There is a different name in different localities. 
Mr. RAKER. Isn't jack pine the little, low, and the stumpy pine?

Mr. Hawley. I will withdraw the term "jack pine." I said "jack pine" because that is what it is called locally sometimes. Now, the Government will make a very good exchange, getting a compact body of land that is easy to administer, covered with good timber, the yellow pine. The company will be at a loss so far as the timber value is concerned, but they will save in distance when building their main canal, and that saving will benefit the settlers that will come in there in reducing the price that they will otherwise pay for that land on account of increased cost in construction.

Mr. Picketw. You are standing there pointing to a map that none of us can see. I must confess that I do not know what you are talking about.

The Chairman. Don't they also gain in the character of the land?

Mr. Hawley. Yes, sir. The lands are located in the Paulina National Forest, which is this section of the State of Oregon [indicating].

Mr. Picketr. Those are the lands you want to incorporate in this bill that you want to have exchanged?

Mr. HAwley. Yes, sir; the lands are located right in here.

Mr. Picketт. I don't know anything about it, because you were pointing to a map on the table.

Mr. Hawley. An old wagon road land grant ran down through this section of the country. Subsequently, these lands were acquired by another body of men who desire to irrigate their holdings. At present they own the odd numbered sections, and the Government owns the even numbered sections, and it is all within the boundaries of the national forest. The upper part is covered with a good deal of yellow pine and very valuable timber.

Mr. Volstead. Is any part of this land in litigation in those wagon road land-grant suits?

Mr. Hawley. No; this is entirely different from the Oregon and California land grants. That land lies within 30 miles of the railroad right of way and on either side of it. This land lies at a much greater distance.

Mr. Volstead. Was this grant made upon any condition such as the lands involved in those suits?

Mr. Hawley. No, sir; this is granted without conditions. It has been patented for years.

Mr. Volstead. There is no condition in the grant?

Mr. Hawley. No condition at all; they own the land in fee simple.

The company has filed under the laws of Oregon on certain water rights here, which will expire with the extensions granted them on the 1st of April. If they can not get this exchange by that time they will begin their irrigation and irrigate the odd-numbered sections both in the northern and southern portions of the land. But if they can exchange their lands, consolidate the Government holdings in the national forest with the good timber, they will then get a consolidated body down here, with timber that amounts to nothing, practically, and will get a comparatively level area in exchange for a somewhat broken area in the north. The Forest Service considers that they will get a very valuable tract of timber and the Government will have the advantage there, and the company will have the advantage in that they will only have to irrigate a compact body of land, and that saving 
then will result in a saving to every settler that goes on the land, because he will have to pay that much less for his water to irrigate the land.

Mr. TAYLOR. Is that a Government project?

Mr. Hawley. No; it is a private project.

Mr. TAYLOR. That is upon the assumption that the company will equitably pro rate that.

Mr. Mondell. You think they will get all the traffic will bear?

Mr. Hawley. No; I do not. They assured me that any saving that accrued would be a saving to the settlers; because they want to settle up that land.

Mr. TAYLOR. Theoretically, that is always true.

Mr. Mondell. Has this company surveyed out its main-line canal ? Mr. Hawley. Yes, sir.

Mr. Mondell. Have you any map of the main-line of those canals ?

Mr. Hawley. I have not. They may have been filed with the Senate committee.

Mr. Mondell. If we had such a map showing exactly the lands which lie under their canal line, which would be the lands they would desire to exchange, it seems to me we would be in a very much better position to pass intelligently on this matter than we are, as the bill gives the Secretary general permission to make the exchanges.

I can see that it might be very advantageous both to the forest reserves and to the people to the settlers who are coming on the irrigable lands under the canals under private ownership. But in the absence of any definite information as to what lands come under those canals, and therefore what lands the company would care to use in exchange, we are called upon to pass on a very general piece of legislation, which doesn't bind the company to exchange all of its land under its canal or any definite portion of them for lands outside, and it might be that the company would desire to make only certain exchanges of lands under its canals for lands outside, still leaving the forest boundaries as they are, with no reduction of the cost of administration, and still leaving the public and private lands intermixed as they are at the present time.

Mr. Hawley. Well, that could be done if you think it to be necessary by an amendment providing that they must exchange all of their lands. But I understand that they wish to exchange all of the lands in the northern part for an equal area in tbe southern part. They will not retain any of their lands in the northern portion, in my judgment, but you could meet that objection by putting in an amendment providing that they must exchange all of their lands in the northern portion for lands in the southern portion.

Mr. RAKER. Has there been any application to the department for ditch and canal rights of way to the Secretary of the Interior?

Mr. PotTer. Yes, sir. It is my understanding that there has been such an application.

Mr. RAKER. Their files would show this whole thing in good shape.

Mr. Potter. I am quite sure that they have on file in the Department of the Interior a map showing the right of way.

Mr. RAKER. They have filed on the water rights and you say it expires April 1.

Mr. Hawley. In about 30 days. 
Mr. RAKER. They have a year in which to commence their work after they file their notice?

Mr. HAwley. No; they must begin by the 1st of April this year.

$\mathrm{Mr}$. RAKER. I mean from the time of filing?

Mr. Hawley. From the original filing; yes, sir.

Mr. RAKer. Now, if they commenced work on any part of that ditch in any place in good faith, to carry out, irrespective of what they get from the Government, whether it is an exchange or not, the water right will be maintained just the same, won't it?

Mr. HAwLEY. If they don't get the exchange they intend to consider that the Government will not make the exchange, and begin at the northern limit of the holdings, and irrigate it in that way. They can't very well begin anywhere else, because the contour of the land is such that if they are going to irrigate all their holdings, they will have to begin at the north.

Mr. RAKER. That project will cover all of their holdings on the odd sections; that is all.

Mr. Hawley. Odd sections. If they do not get the exchange, they are going to begin at the north end of the present holdings.

Mr. RAKER. If they make the exchange, they wouldn't have to go so far north, because that would be an exchange for Government lands.

Mr. Hawley. Yes, sir.

Mr. RAKER. In other words, they would construct one big canal down south instead of making a lot of lateral canals.

Mr. Hawlex. They would construct their main system, beginning at the upper end of their holdings.

Mr. Mondell. Is the topography of the country such that it is possible for them to divert the water at the northern end of the territory they own?

Mr. Hawley. Yes, sir. They have water rights on the lakes in the north for that purpose.

Mr. RAKER. Then, it will require two systems.

Mr. Hawley. They have five little lakes from which they expect to build if they do not get an exchange; they will build canals and take water from those three places.

Mr. Raker. Do you know what lakes they are? Is it Crescent Lake; is that one of them?

Mr. Hawley. Yes, sir.

Mr. RAKER. Another one is Fish Lake?

Mr. Hawley. Yes, sir.

Mr. Mondell. Do you know why, if this company has been desirous of having this exchange made, they have not called upon the Agricultural Department to have an examination made locally and in detail ?

Mr. Hawley. I think such an examination has been made. I was reading from the report.

Mr. PotTer. Only in part.

Mr. RAKER. Just going right down with a few more questions with regard to water rights. There isn't any question that these people, if they made the filings, would have their canals and ditches all surveyed, and actual and bona fide commencement of the work before the 1st of April, would retain all of their rights, so far as the filings are concerned. 
Mr. Hawley. They would retain their rights where they had begun actual construction.

Mr. RAKER. The water on which they began to work.

Mr. Hawley. Yes, sir.

Mr. RAKER. Their purpose, then, is to get the south part of the tract, 48,000 , so that it will be one compact body?

Mr. Hawley. Yes, sir.

Mr. RAKER. Have you estimated what amount of timber there is upon the 48,000 acres of land that the Government now owns on the south part of this tract?

Mr. HAWLEX. Forty-eight thousand acres in the whole tract, half is owned by the Government and half by the other people.

Mr. RAKER. Has there been any cruising on it?

Mr. Potter. We haven't completed cruising it. We have examined a part of the lands, but did not finish our examination.

Mr. RAKER. You were to do that?

Mr. Potter. Yes, sir.

Mr. RAKER. Has there been any cruising in the northern part of this what you call the yellow pine, to determine the quantity of pine on each particular 40 acres or each particular 160 acres?

Mr. Potter. No, sir.

Mr. RAKer. None at all ?

Mr. Potter. No. Not any estimate of the timber.

Mr. RAKER. Has there been any of these lands in the northern part cut, the original timber?

Mr. HAwLEY. I doubt it, though I have no information.

Mr. RAKER. Hasn't there been several sawmills up on that road, what we know as the old road that goes from Eugene and cuts through the timber there? Has there been any sawmills there cutting off this land?

Mr. Hawley. I have been in that section and I never saw any evidence of it, but I couldn't say whether there have been or not.

Mr. RAKER. What is the value, the present market value, of this land in the southern part of the tract, which you say is now owned by the companies? What do they estimate its value; do you know?

Mr. HAwLEY. It is worth but very little in its present state.

Mr. RAKER. $\$ 10$ an acre?

Mr. Hawley. No.

Mr. RAKER. $\$ 5$ an acre.

Mr. Hawley. No; I wouldn't say that. It is just pummice soil. It gets very dry. It has a little grass in the spring, and it gets very dry in the summer, and it is no use in the winter.

Mr. RAKER. It is a level tract and it can be irrigated?

Mr. Hawley. Yes, sir; they can irrigate most of it.

Mr. RAKER. If water is obtained on that land it will be worth from $\$ 75$ to $\$ 200$ an acre.

Mr. HAwLEY. Yes; it will be worth-I hardly know exactly how much to say-but it will be worth a good price.

Mr. RAKER. This land in the northern part, is that susceptible to irrigation? The land owned by the Government.

Mr. Hawley. There are portions that they will irrigate if they can not make the exchange.

Mr. RAKER. Is any of that land now owned by the Government on the northern end of the tract susceptible to irrigation? 
Mr. Hawley. I think some could be.

Mr. RAKER. Do you know about how much?

Mr. Hawley. No; they didn't state how much to me.

Mr. RAKER. How much Government land in the northern half is susceptible to irrigation?

Mr. HAwleY. I do not know.

Mr. RAKER. As to this south half in particular. If these people go ahead and complete their project, as it now is, and the Government still owns the southern part, after they have brought their ditch and run it down on these odd sections, of course the Government lands will have been enhanced in value from $\$ 5$ and acre up to $\$ 50$ and $\$ 75$ an acre; won't it? Then they have to put the balance of it as water rights. If the Government wanted to abandon this land as a national forest and open it up to homestead settlers, you would then have a tract of land about 48,000 acres of land, under an irrigation system, ready to turn over to the homesteaders; won't it?

Mr. Hawley. The Government owns only 24,000 acres. I don't suppose the Government would ever open this to homesteaders.

Mr. RAKER. Why not?

Mr. Hawley. My supposition is that they would keep it as a national forest.

Mr. RAKER. Now, if this private institution can so change that land by a little grubbing and handling to make it tillable land, why couldn't the Government throw it out of the reserve and open it up to homestead settlers?

Mr. Hawley. They could, if they would go to the expense of putting in an irrigation system.

Mr. RAKER. Let us leave out the irrigating system entirely for just a moment. The land is worth nothing for agriculture without irrigating. If the Government should see fit hereafter to throw this land open for homesteaders for farming purposes, from your statement it is more valuable for that purpose than it is for a national forest.

Mr. Hawley. The lower half is more valuable.

Mr. RAKer. The lower half. Now, if this company had already procured ditches and canals down through this land and they would have to cross the Government land as they wanted to do then there would be a system, a water system, ready to be applied to this land, wouldn't there?

Mr. Hawley. I don't see where they would get their water. The water would belong to the company.

Mr. RAKER. That would be the fact if the ditches are there and the water has been stored in the mountains. These people bring their ditches down across these particular tracts-

The Chatrman. On the northern part?

Mr. RAKER. On the southern part. Isn't that right?

Mr. Hawley. The system would be there.

Mr. RAKER. Now, the Government throws this open from a reserve and permits it to be occupied by settlers, and those settlers under the laws of Oregon would be entitled to demand and receive their proportion of water from that canal, paying for it under the State utilities bill.

Mr. Hawley. They would if they had the water to spare. Those already on the project and having the water would have the use of 
the water. Those on the northerm part of the present tract would be using considerable water that would be otherwise available to be used on the southern part if the exchange was made.

Mr. RAKER. Is that the character of your law in Oregon now, that the first fellow who appropriates water may cut off the subseruent man when it is for public purposes?

Mr. Hawley. The man who burs water from the ownel al the ditch has the right to have it maintained.

Mr. TAYLOR. The first man can enjoin the Gorermment from selling to the second man.

Mr. RAKer. Let us see now.

Mr. Taylor. They can in Colorado.

The Charman. If the exchange were made, area for arca, wouldn't that give the road company a considerable amount of land above their high-line ditch?

Mr. Hawler. No; if the exchange is made -

The Chammin. In an exchange of that a consolidation of each interest would take place, giving the Government the northerm lialf and the company the southern half; wouldn't that throw some of the company's land above their high-line ditch?

Mr. HAw LEx. There might be areas where there are ridges, whele they couldn't get their water on the land.

The Chamman. They will take it anyway?

Mr. Hawler. Yes; they will take it anyway. Then they would release, as I understand it, the water rights that they have on the northern half.

The Ciraman. Suppose we hear from Mr. Potter. Perhaps he can make this matter clear. Mr. Potter, you have gathered from the discussion what the crucial difliculties are. Will you address rourself to them?

\section{STATEMENT OF MR. E. F. POTTER, ASSOCIATE FORESTER, UNITED STATES DEPARTHENT OF AGRICULTURE.}

Mr. Potrer. Mr. Chairman and gentlemen, from the examination we have been able to make of the land we are satisfied that the exchange which the company desires to make would be advantageous to the Government from the standpoint of the national forests, for the reason that the lands which they propose to give are worth more for raising trees than the lands which they wish to surrender. Tre have had an examination made of part of the lands, and I desire to read a few extracts from the district forester's report:

[Extracts from district forester's report.]

The soil over the whole area shown on the attached map is of a character peculiar to this locality, and contains practically no loam or silt. It is in the main pure pumice to a considerable depth. It is very light and granular, and is formed from large pumice stones deposited on this area hy volcanic action in the past ages. During the heat of summer the soil becomes exceedingly dry on the surface, while at varying depths, from a few inches to a few feet, it is not only moist, but in many cases even contains free water. Although there is considerable moisture at varying depths, it docs not appear to be available for plant life on the surface, consequently it has been considered that irrigatiou is necessary for successful agriculture. The portions shown in red on the map are covered with lodgepole pine, a moisture-loving species. The lodgepole pine areas, it will be noticed, lie usually quite level and just below the benches and steep country on which the yellow pine is ustally find. The yellow pine areas shmm in 
orange color include the rougher portions of the tract. In fact, some of the lodgepole pine areas are of too steep a slope probably to permit of successful irrigation in a soil which is so extremely liable to erosion as this pumice soil, which readily floats in water. It is therefore plain that any irrigation company with agricultural development in mind would de:ire very much to exchange the areas of uneven topography for level ludgepole pine lands." The decreased cost of irrigating a compact body of land, together with the more level character of the lands desired in exchange, makes the exchange, it seems to me, advantageous to the corporation.

I understand that the Gremon Land cirporation is intere:ted in naking an exchange of their lands for level lodgepole pine unappropriated (iovernment lands in Tps. 27, 28, and $29 \mathrm{~S} ., \mathrm{Rs} .7,8$, and $9 \mathrm{E}$. The lodgepole pine on this area is of a rather inferior character. Very few tie trees can be obtained per acre; the pine is valuable mainly for fuel, feneing, and pulp word. Many areas of considerable size can here be found with no growth at all upon the land, as shown in the photographs exhibited by the corporation. The land is much less valuahle for forestry purposes and more valuable for agricultural purposes than the yellow pine land claimed by the corporation, which they desire to reconvey to the Government in exchange. So far as the Forest Service is concerned, it seems to me that there is no doubt but that the Government is obtaining not only land having an intrinsirally greater value for forestry purposes, but also land containing timber which at present is much more valuable than the lodgepole pine land.

Owing to the fact that the Forest Service has not in its possession a definite location of the lodge pole and the yellow pine areas, it is not possible to inform the corporation just what lands we should give up in exchange. ('onsequently; it is advisable that any bill which receives your approval should allow the selections to be made by us after careful field examination.

The Chairman. Allowing what selections to be made?

Mr. Potter. The selection by the company of the lands which it will get in exchange.

Now, the only photographs I have are these two, which you may pass around. They will give you a pretty good idea of the character of the lands which the company desires to secure.

Mr. PicketT. How far is the land from the Klamath Lake?

Mr. Potter. Fifty miles, I should say.

Mr. Pickett. And how far from the Southern Pacific Railroad, the main line?

Mr. RAKer. The new line will run right through it.

Mr. Potter. The new line will run right through it. It is at least 75 miles anid possibly 100 miles to the present line.

Mr. RAKER. The railroad is at least 75 miles to 100 miles west of the land.

The Charranan. On the theory of the bill, isn't it the object of making each party owning alternate sections, to yield up the alternate sections, and the other party yield up sections in the other part? There isn't any selecting to do, is there?

Mr. Mondell. It wouldn't be necessary for the company under this legislation to surrender all of its land in the northern part. They could surrender such portions of the land in the northern part of the reservation for such portions in the southern part as they desired to irrigate, such portions in the northern part of the reserve as would be necessary to secure the acreage in the southern part that they desired.

Mr. RAKER. Susceptible of irrigation.

Mr. Mondel.. I judge from this map, that the lands they would desire to secure are not in a compact body. He refers to the lodge pole pine lands as being the lands in red.

Mr. PotTer. Yes, sir; that is correct.

Mr. Mondell. And the other is the land in orange.

Mr. Potter. Yes, sir. 
Mr. Mondela. So there is some territory in the southern part of the reserve which the company perhaps could not irrigate because it would be abore the line of its canal, as indicated by the topoeratphy.

Mr. Potter. Yes, sir. And this was outside of their errant. 'Their grant was there [indicating].

The Cunmuar. I understood Mr. Mawley to say that they would accept the land above the citeh in oreler to make a solid dividing lines of the land between them.

Mr. Mawler. I think I comld say that if it is amemeled repuiring then to exchange all lands in the norelhern portion for the lamels in the southern portion, subject to the approval of the secretary of Arrieulture, that would be satisfactory.

Mr. RAKer. This railuad going through this land, and this water project being developed, this lamil in the sonthern part being more valuable for agrieulture than for forests, wouldn't it be a good policy on the part of the Government to throw open all of this lanel on the southern part and almit settlement and permit settlers to take it up) as homesteads or desert entries, and then deal with the other parties in regard to water rights?

Mr. Hawler. What adrantage would it he to the settlere, Judge? He couldn't get his water any cheaper muler one arranerenent than uncler another, and the lands ane practically of no value without water. He would get it just as cheaply liom the company and he would get it at once, and the State of Oregon would have the benedit, and the people who arme to that section would have the benefit immediately.

Mr. RAKER. Ile would get it from the Government for homestead purposes. He would only have to pay so much for it for the improvements, putting it in fine shape, and he would get his water from the company at just the same price, with the same regulation and under the same condition that every other man under that project geets his water.

Mr. Fergusox. Suppose there is not enough water and it has been appropriated prior to that?

Mr. Raker. According to their statement thay have water to irrigate the whole thing.

Mr. Hawler. Twenty-four thousand acres.

Mr. Laffertr. 'This identical bill, here's the Senate report on the bill. There is a Semate bill which is also before this committer. It has passed the Senate and there is the report.

Mr. Potter. I would be glad to answer any questions in reference to the matter referred to by Mrr. Raker regarding the allowing of these lands to be taken up as homesteads for seitlement and would say that this is already provided for in the forest homestead act of July 11, 1906, whenever the condition of this land is such that it would be suitable for agriculture. Of eomrse, in its present condition it isn't what we consider agriculture land. It isn't land upon which crops can be raised until an irrigation system has been dereloped.

Mr. RAKER. I think it is worth the eonsideration of this committere Some of the farmers down in the Salt River. Valley--their testimony before the Committee on Imigation-showed that they are holding these lands since the project has been completed, or jartially completed; that this land has increased in price without any water right all the way from $\$ 75$ to $\$ 100$ to $\$ 150$ an acre. Whether the private 
individuals made that amount of money from an expenditure of $\$ 10$ $10 \$ 20$ on up from the original price of what they would figure of $\$ 10$ or $\$ 15$ on it from $\$ 75$ to $\$ 150$ an acre. If this land is exchanged now by the Government to the company, the Government says to the settler that comes in there, "Take this land; we, the Government. will give you a permit to make a home upon it because you are a citizen, but we will permit this prirate company to charge you for that land, without water right, all the way from $\$ 50$ to $\$ 100$ an acre." That is the thing which appeals to me in the matter. Under the law of Oregon, as well as of California and others where private companies have been permitted to make diversions of water for public purposes, it must supply to all alike as long as it has a sufficient amount of water, and permits of no discriminations.

The Chamman. Doesn't it recognize priority?

Mr. Raker. Not in public utilities. Otherwise they could thwart the very purpose of it. All of the contracts made in California, on the basis that under a private system you would have private water rights to particular lands, the Supreme Court of the United States has held those contracts void as against public policy.

Mr. MIONDELL. You, unfortunately, in California, have a constitution which recognizes the law of riparian rights which you have tried to cualify by court decisions and you have had a hard time to do it. But the State of Oregon has, I think the law of appropriation, just as in the other Western States.

Mr. RAKER. The law of Oregon is stronger than that of California. so I am somewhat familiar with the law of Oregon upon that point.

Mr. Mondelz. There ean be no question, of course, but that if this company provides a system of irrigation for the irrigation of its own lands, with only sufficient water for irrigation of its own lands, there is no power on earth which could compel them to divert water to other lands which they had on their own expenditure diverted for their own lands. There is no power on earth could compel them to surrender that water to any other lands. If they only had water enough for the irrigation of 48,000 , or 40,000 , or 30,000 acres, or whatever it is, it is to the alvantage of everybody to have those lands in a compact body, if they are irrigable in a compact body, and the only question in this matter, it seems to me, is that it isn't clear as to just how much of an exchange it is proposed to make.

It seems to me that if it is intended to give the company all the irrigable lands under its ditches, which it does not now own, in exchange for better timber lands, which it does own, and we had that matter clearly before us, there would be no question but what the arrangement would be wise both from the standpoint of the people, who are to inhabit those lands, and from the standpoint of the Govermment, as owner of the forest reserve. The only difficulty is that the legislation isn't definite enough, and I don't know how you can make it more definite, on account of lack of information.

Mr. Hawley. That could be corrected.

Mr. MoNdell. If the Secretary of Agrieulture had made an examination of the lands lying below the company's supposed ditches, and we knew what those lands were, it would probably be wise, I assume it would from what we know, for Congress to say that the Govermment may make the exchange providing it secures good timber land in 
exchange, so that the (ompany ane consolidate its holdings moler its canals.

Mr. Potrer. We have made a pretty complete examination of at large portion of the lands, Mr. Mondell, and the lands which the conmpany proposes to irrigate, but we haven't male a careful examination of the yellow-pine lands which they propose to give us in exchange.

Mr. Mondell. Do you know the lodge-pole-pine lands that are talked about have very little timber on them?

Mr. Potter. Very little timber, and they are level lands.

Mr. Monden.. They are not lamels that are likely to produre valuable timber?

Mr. Potter. No; they are not. If they were even put under the ditch and retained in Government ownership, and it was not possible for the Government to secure water from the company for irrigation, they wouldn't have any great value for agricultural purposes. Without irrigation they wouldn't be as valuable for the purpose of raising timber as the higher, rougher lands, which produce naturally yollow pine.

Mr. Pickets. Is it not true that in the southern half, though, greater areas of lands are adapted to agricultural purposes?

Mr. Potter. Yes, sir; it is practically level, as shown by these photographs, and there is a scattering growth of lodge-pole pine. The northern half is rough and hilly.

Mr. Picketr. So that in effect we would be exchanging lands which are hardly adapted for agricultural purposes for lands-we would be giving them lands that are adapted for agricultural purposes and receive those which are not. Let me ask you, what would be the value of these lands if they were subject to irrigation?

Mr. Potter. I would have to make a very rough guess on that. I should say, though, not less than $\$ 150$ an acre after they have been developed and put under cultivation.

Mr. Pickets. It would be, then, very good business on the part of the corporation.

Mr. Potter. It would.

Mr. Picketr. They would be able to control the development of the lands.

Mr. Potter. Yes, sir; if they made a success of that proposition, of course it would be a good thing for them.

The Chairman. What would the value of them be as they are now, without any irrigation?

Mr. Potrer. The value without taking into consideration the possibility of their reclamation or the nearness to the new railroad would be very low, probably not over $\$ 2$ an acre, but of course the fact of the railroad coming in and being near to them, and the fact that they are possibly lands which may be reclaimed by irrigation, would give them a higher value. It is, of course, almost impossible to say what that value would be.

Mr. TAylor. Why does not the Forest Service open all these lands to homestead entry?

Mr. Potrer. We wouldn't hesitate at all to open this land to settlement if anyone wanted to take it under the prevailing conditions.

Mr. 'TAYLOR. If a homesteader wanted to go on this land he would have to go and make arrangements with the company for water?

Mr. Potrer. That is the point exactly. The land in its present condition is of no value to the homesteader. 
Mr. RAKer. Isn't that the condition in the case of practically all of the remaining public domain that is not forest or hills?

The statement I intended to make was that water appropriated and diverted by a corporation for its own individual purposes is eontrolled just the same as by a private individual, but water appropriated by a corporation on a private individual for a public purpose or use becomes a public utility and it must be served to all alike, equal to the ranging price provided either by the public-utilities commission or by the county commissioners. Therefore, anybody' on the project has the same right as the other.

Mr. Monoes. The right to divert water is the right to divert it onto certain lands.

Mr. RAKER. Not at all.

Mr. dínenes. Fnder the law of the State of Oregon an application to divert water is an applieation to divert and use it upon certain specific lands. Fortunately the State of Oregon has gotten away from the idea of private ownership of water to the idea of public ownership of water, and the diversion that you are discussing that these people have made is, T assume, a diversion for the irrigation of certain lands. They have the right to irrigate those lands for which they have made the application, and until those lands are irrigated that water is dedicated to those lands, not to the company, but to those lands, and no one who hasn't taken the trouble to acquire any rights can come in and say give us the water which has been dedicated to these lands for our lands. If there is a supply of water after the lands to which it has been dedicated have been irrigated, then of course those waters can be used on adjacent lands.

The Cinamanas. The court could only interfere wherever there was waste.

Mr. RAKer. It depends upon the application, whether there is sufficient water for the use of others.

Mr. LAFFERTY. My understanding of the law of Oregon is that the first man who appropriates the water is entitled to its use, unless there is a sufficient amount for subsequent users.

But about the merits of this bill, I would like to say just a word, as it appears to me that it is to the advantage of the people of the country generally to have this exchange made, as well as to this company.

The Champan. Just a question on this bill as it comes from the Senate. Do you see anything in the bill as it now stands to prevent the land company from picking out certain lands and saying to the Government, We will give you that, and only that, and you give us land in equal area for it? We do not propose to make a complete exchange and allow you to consolidate us on one side of the line, or to consolidate ourselves on the other side. Does it leave it to the land company to make such selection as it chooses out of those 24,000 acres, acre for acre?

Mr. Lafferty. I understand the bill just the other way exactly. Just the opposite to that. The proposition is left entirely with the department to say whether or not this exchange shall be made even after the bill becomes a law.

Mr. Potter. Yes; that is right.

Mr. LAFFERTY. The department wrote the bill. 
Mr. Taylor. The department can make the company relinguish all of the land in the reserve.

Mr. LAfFerTy. Or take nothing.

Mr. Moxdell. Or take any attitude between those two extremes?

Mr. Infferty. Yes. The Govermment has the absolute power under the terms of this bill to say how the exchange shall be made or refuse to enter into the exchange altogether. And while it seems the point that Mr. Raker made here is that the Govermment could obtain an advantare by refusing to make the exchange, by compelling the company to run those ditches through on the odd sections, and thereby enhancing the value of the Government lands, I think that would be very unfair. In the first place this irrigation project will not go through unless this exchange is made, but the proposition to force a private company to run its irrigation ditches in order to make the Government land more valuable would be unfair and unreasonable.

Mr. RAker. You didn't quite get my view. I feel that as a member of this committee I always have the liberty to direct my questions as they appear to me to get the facts from the witness. Iy feelings, I try not to divulge. I ask questions to get information. I asked this question for the purpose of finding out whether they have already sought rights of way across this Govermment land, if the ditch could not be constructed as well along those limes as across the Government land, and if they already have those plats on file with the Secretary of the Interior.

Mr. Lafferty. These lands are held by the Covernment in trust for the people of the United States. Now, then, certain sections in the southern portion are going to be given up for certain sections in the north, in which the people of the Inited States will get the equitable title, and not only that, but they will get more than they are giving up.

Mr. RAker. Part of that land in the north was to be cultivated according to Mr. Hawler's statement. It is owned by private individuals, isn't it ?

Mr. Lafferty. Yes, sir.

Mr. RAker. Now, as a matter of fact, this entire southern part of this tract can be put under cultivation, part of it by the company and part of it by the Government, and they can permit homesteaders to go there. Wouldn't it be better to take that much land out of the forest reserve and put it into actual use?

Mr. Lafferty. If the forest department is disposed to open up any portion of this land to settlers, it would be in a much better position to do that if this exchange is made, by opening up a solid body, the north half, to settlers, than it would now to open a tract which is owned alternately by the Government and private holders, for nobody wants to go and settle in a section where those conditions obtain. They have the disadvantage of having the company holdings there and they can't develop the neighborhood.

The Chamman. Ilow much of this is susceptible to irrigation?

Mr. LAFFERTY. Of the northern half?

The Crmarman. Yes.

Mr. Laffenty. I think practically all of the northern half. Practically all of this land is capable of being irrigated. Now, in order to be used-of course, if this company is going to take the southern half and use the water, appropriate the water that the public might use on 
the northern half of the land, make an earlier appropriation to the southem half, it would leave the Government with the northern half without any available water; and that would be probably a bad arrangement; but there is nothing of that kind-this company is going to take this water from a point. down adjacent to the southern half, and it is going to abandon its rights to the water in the northern half.

Mir. Hawler. That is their plan as I understand.

Mr. LAFfenty. Yes; under this bill. \&o that the rest of the people have been very well protected by the forestry department in this bill.

Mr. RAKER. Now, if they are going to do this, what brought about this change? If they originally figured upon Crescent Lake and waters right there, with their ditches and canals, and the Government hasn't anything to do with their original license, why should they now seek to abandon the entire north and simply apply to the south?

Mr. InAFEerty. Because the Government demands that they shall do so. You have the idea, and it is a very good one, that the Government may want to open up this northern half to settlers. If it does so, it wili have to have some available water. This private corporation has got to relinquish its clain to the water available for the northern half.

Mr. RAkER. But I understand from Mr. Hawley that the northern half is filed on and they have been working on a ditch, bringing a ditch down from the north.

Mr. Hawlex. If no change is made they plan to begin at the north; but if an exchange is made, they intend to abandon their water rights in the north.

Mr. LAFFentr. And here is where they take out the water [indicating]. They abandon their claims on what they have already filed on here [indicating].

The (maIRman. Is there anything regardless of that which would compel them to abandon their claim in the northern part?

Mr. LAfFERTX. No; they could bring their ditch down from the north half. If they have surrendered and have no lands in the north to irrigate, they will have no ditch there.

Mr. RAKer. That wasn't quite my question. That would leave the option with them whether they would or not give it up. There is nothing that would compel them to abandon their claim on the northern water supply, and they could still retain it.

Mr. Laffarerty. Only to the 1 st of $A$ pril. If they didn't begin their ditches by the 1st of April they would lose the water that they hadn't begun to use.

Mr. RAKER. Suppose this bill passes as it is now, what guarantee have we that they will not retain their filing on the northern water supply, anyway? Doesn't that denrive the Government from getting water on the north?

Mr. 'TaYlor. Why shouldn't we put in a clause requiring them to relinquish that?

Mr. LAFFerty. I have no objections to that. The department ought to require that to be done anyway if that is the understanding.

IIr. HAwLEY. They told me that they were going to abandon it if they obtained this exchange. I have no objection to your putting into the bill any safeguard that you think advisable. 
Mr. Ferguson. Suppose it be required as a part of the exchange that this water right be reserved to the Government?

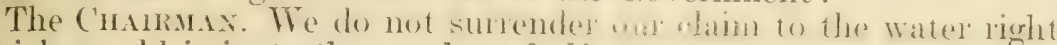
which would irrigate the northern half.

Mr. MaWLeY. A provision could be inereat in the bill, corering the releasing of the water rights on the north.

Mr. RAKER. I understand from your statement that the future reservoirs, with the canals and with the water supply that they have arranged for. would be sullicient to imgats the entire southern part, both Government and private land.

Mr. LaAfFerTy. Irrigate $24,00(0)$ acres wheh the have alranged for.

Mr. RAKER. That includes the Govermment lands?

Mr. Lafferty. What is now Government lands.

Mr. RaKen. And that will not thein need the northern reservoir system?

Mr. LAFFerty. No, sir.

Mr. RAKER. Then the statement mare before by some gentleman that there wouldn't be water enough for the whole tract ; there isn't anything in that, is there, because both syutems furnish enough water to irrigate the whole tract?

Mr. LaAFEerTy. I don't think the ammont of water in the north; but if they do not make the exchange they will bring ditches from two places in the north, owing to the contom of the comntry, down to the south half.

Mr. RAKER. Isn't it as a matter of fust very largely against their interests to abandon that water line in the north because they can bring it down on the southern part, too?

Mr. LAFFERTY. No; if they can get their land in a body, they can make their canal so much shorter out of Fish Lake and adjacent water. They wouldn't go up to the northern portion and bring the canal in a zigzag manner for 25 to 30 miles. There would be so much evaporattion, and so much opening into the soil. that it would be a loss to them to do that.

The Crammax. When the inater an be obviated so easily, I think it is hardly worth while to reason about it.

Mr. Hawler. Put any reasonable limitation you see fit in the bill. and I think the company will agree to it.

We endeavor to develop our State. Here is a matter that is going to put under cultivation 24,000 aeres and furnish homes to many people and which will be on the main line of a railroad. It will mean a number of new citizens for our State. It is largely a local matter. The Government will make an advantageous exchange. I urge that you take a favorable view of the bill and pass it.

Mr. Picketr. You talk about opening it up and settling it. That is just the sticker in this thing from my viewpoint. If you were opposed to opening up and settling and criving homesteader's the right to go in there, that is one proposition. But it seems to me that we are turning orer this land to this corporation when they have got the strategic situation where they can hold a follow up for any price they see fit. It seems to me like a purely commercial proposition.

Mr. Hawlex. They must sell their lands. They put under water on a certain expense. But they will he compelled to sell their lands - at the price the sattler will agree, and rin affoml, to pay. They will 
under that restriction as to price; it seems to me it would talie care of itself, as it does in every other irrigation project throughout the WVat, and there are many. Is a general proposition in the case of irrigation projects, the water is furnished at as low a price by private corporations as hy the Gorermment reclamation projects, so I am informed.

The ('mirum. ()n that point, it seems they have got that right, and we can't take that right away from them.

Mr. Picketr. That may be true. I had looked at their blue prints, and the way they have colored it up), there is very much good land in the northein part owned by the company to exchange for the good land which they want in the southern part.

The C'mArusir. Is there any limit in the amount of land that a private corporation may hold in Oregon?

Mr. IAafferty. No.

Mr. RAKER. They own about $1,000,000$ acres originally.

So that I mav be in a position simply to take fair action in the matter, would the chairman of this commit ce have present the application of this compuny for water rights across the national forest of the Government, the Paulina National Forest Reserve, from the Secretary of the Interior; will he kindly have some one bring it up?

The Ciraminan. I think we ought to have more light.

Mr. HAwLEY. I don't think you will find them there; they are probably filed with the State engineer, in Oregon.

Mr. Raker. You do not umlerstand the right of way application.

Mr. ITawrer. It is only 30 days before the exchange will be off, as their rights will expire in that time, and that I respectfully repuest the committee to take into consideration.

Mr. RAKER. I am ready to-morrow, if you bring that up.

Mr. Lafrenty. There is just one thing about this water ight: As I understand they filed on the ('rescent Lake water right hefore the forest reserve limits were extended over this line. Now, the proposition is to agree to make this exchange on such terms as may be presrcibed by the department. The department is going to prescribe as one of those terms of exchange that they surrender their right to this Crescent Lake water, and that will absolutely guarantee that this water will be held for use in the northern part.

The Charmax. Do you consider that this committee could act on what you say the department is going to do? We ought to have some evidence.

Mr. L.jfferty. We must presume the department will protect the Government in the matter.

The ('marrman. We can't go onto the floor to defend this bill on such a statement as you make.

Mr. Potrer. 'The Pauline Forest was created last year from a part of what was originally called the Cascade Forest.

Mr. RAKER. Aceording to Mr. Laflerty's statement they already own the water right.

Mr. MIondell. That is, they have a right to apply it to these lands. Don't say that anybody actually owns water.

Mr. RAKER. Oh, yes; I have said it many times, in the courts. We do it in California.

Mr. Mondell. Here is a suggestion, I don't know that it can be carried out at all. But there is a way in which this matter could be adjusted satisfactorily to ererybody. If there are certain lands which 
the Government owns under these ditches that ought to be irrigated, there is a way lor this company to irrigate them and get paid for doing so, and that is to have us pass a bill subject to the discretion of the Secretary of Agriculture, to his approval, to allow these lands that belong to the (rovermment, under the ditches, tor he segregrated under the carey Act. Them the company would (ontrol, as to their disposition, but the only charge they could make would he the charges fixed by the State of (Oregon covering the cost of rectamation. I don't know if it would be possible or practieable to do that, but that would be one way out.

Mr. RAKer. I would not like to express myelf on any subject or any matter eonnected with it until we get all of the evidence in here. I understand the chairnan will bring the rest of it here. When we get that all in, then of course we ean be in better shape to present the matter.

The Chamman. You are the chairman of that subcommitten, Mr. Raker?

Mr. Raker. No, sir.

Whereupon the committee adjotined to $10.30 \mathrm{a}$. m. to-morrow morning, February 29.

\section{Committee on the Public Lands, House of Representatives, Thursday, February 29, 1912.}

The committee met at 10.30 o'elock a. m., IIon. James M. Graham (acting chairman) presiding.

The Chamman. This is an adjourned meeting from yesterday, and the committee will please be in order. The pending question is Senate bill No. 4745 .

\section{STATEMENT OF HON. W. C. HAWLEY, A MEMBER OF CONGRESS FROM THE STATE OF OREGON.}

Mr. Hawler. I would like to call the attention of the committee, in a summary way, to the situation here. The land to be exchanged lies four and one-half townships long north of the Kilamath Indian Reservation and is two townships mide, covering part of nine townships. I have a letter from the assistant secretary of the Oregon Land Corporation-which is the name of the company you desired, Mr. Chairman-which says:

This entire tract of land, extending from Crescent Lake to the Klamath Indian Reservation, is irrigable from Crescent, Odell, Summit, and Fish Lakes and Big Marsh, and all of these lakes have been filed upon by us with a view to irrigation of these lands. Our trouble in the past has been that we did not hold the title to the lands, and our irrigation project has been accordingly retarded. About two months ago [Jan. 1, 1912] we purchased these lands outright and now have a clear deck for action, and we wish to get busy.

The Chamran. About what time did you purchase it?

Mr. Hawler. About the 1st of November from a land-grant wagon-road company.

Mr. Raker. Oregon Military Wagon Road Co.? 


\section{Mr. Hawley. Yes, sir. The letter further says:}

As you will note by reading our letter to the Forester, an exchange of these alternate sections through the strip in such manner as to consolidate the lands on the south half for our irrigation project and the lands on the north half for the forest reserve would be of decided benefit to all parties concerned.

I want to make two observations on two paragraphs of his letter. He says all their lands are irigable from these lakes. That question was raiced yesterday about irrigation projects for the lands the Government might own, which might hereafter be opened to settlers. Now, if the exchange is made, then the lands that they exchange in the north half that may be good agricultural lands, whatever there are of them, could be then opened to irrigation from these lakes upon which they would release their water rights.

In the second place, you will notice he says "to consolidate their holdings" in the south and to transfer to the Enited states their holdings in the north for a forest reserve. The question was raised as to whether they were reserving a part of the lands in the north. His letter indicated the intention to tramsfer to the Government all their lands in the western part of the tract. However, the amendment suggested vesterdar could be inserted in the bill if thought advisable.

IIr. (hairman, an effort has been made to find the plat showing surveys for canals, and Mr. Potter says he has also tuken the matter up with the Interior Department, and it seems that no plat of these surveys has been filed there-it has probably been filed with the State engineer lor Oregon, with whom the water-right filings are also filed.

The Cuminax. How do you hope to get the camals fiom the Government without any notice to the Government?

Mr. Hawasy. They do not. I understand they have applied lor permission to pass over the Government lands.

The Crampax. What we asked for was the location of their canals and the Govermment lands over which they proposed to bring them.

Mr. Hawley. Mr. Chairman, I think the reason why the plats were not filed here is that if the comsolidation is agreed to, the canals will not go over the Govermment lands, except possibly for a very short distance. 'Theil' canals would be all on their' own lands.

The Chatrman. I know, but their filing would be in the theory of consolidation?

Mr. Hawley. But I mean the application for exchange was on the theory of consolidation. I am sorry that the information is not available, but I am sure if it had been available, Mr. Potter would have found it.

Mr. RAKEli. I)id I understand that they had made applieation to the United states for rights of way across the forestry lands there?

Mr. Potter. I suppose that they have, Judge; I wired the district forester at Portland for that information, asking him to wire me whether or not they had made application for a permit, and I have not received any reply to the wire, so that I don't know for certain whether they have a permit or not, but when these gentlemen were. here the. made the statement that they had made application for a permit for the irrigation ditch.

Mr. HA wLEY. I understood you to make that statement yesterday.

Mr. Potter. Yes, that is what the gentleman said, that they had made the application. 
Mr. Pickett. Mr. Potter, what would you say if some plan could be devised under an act like the Carey Act, whereby all of the tillable ground could be opened to settlers?

Mr. PotTer. That would be a very good plan, sir.

Mr. Pickett. What would you say about such a plan as eompared to this measure?

Mr. Potter. I don't know which would result in the greatest good, but any plan that contemplates the development of those lands would meet with our approval.

Mr. Picketr. Would not some such plan acemplish the purpose so far as the settlement is concerned, and at the same time give the settlers the benefit rather than this corporation?

Mr. Potter. Yes. If it was opened under a Govermment reclamation project, or, as was suggested yesterday, by a private corporation under the provisions of an act that wovild ilefine the conditions under which settlers could get the land.

Mr. Hawler. I think your suggestion, Mr. Pickett. Would be a good one, if it was not that half of these lambls are already in private ownership, and these people have a fight on for available water, and one of their ditches will have to be some 25 miles or more long.

Mr. Speer. Won't they, as it is now, in order to carry out an irrigation scheme, have to enet the right of way over the land that the Government owns?

Mr. Hawey. I suppose they would arrange to (oposis the Government lands for as short distances as possible.

Mr. Speer. If this exchange is male, they won't have to go over the Government lands at all?

Mr. Hawley. I was groing on to state that the ditches will be in lands that are porous, and they will absorly a great deal of water. and there might be no water left over from the five appropriations: but I understood them to say their engineers thought that the water they had filed on would he about sufficient for the irrigation of their lands both in the north and south. Now, if ther irrigate their half of it with their main canals and laterals, put in their drainage system, and then you put in another irrigation scheme on top of that, you are going to have confliet and some of the lands are bound to suffer in the matter of drainage. Inder the comsolidated plan the matter of main canals, laterals, and drainage would be taken care of so that none of the lands would be foul or sour by reason of the drainage ditches. I think there is somo alkali in the lands, and a drainage system is very necessary.

The Craminan. Are you prepared to-day to give us any more definite knowledere of the romparative values of the land in the sonth and the land in the north half of this tract?

Mr. HAWLEx. I have no more information; I wouldn't give, as the lands now stand without water, more than $\$ 2$ an acre, while the stmmpage of the timber lane in the morth is quite valuahle, and will be greater when the railroad goes through.

Now, there is another thing. If they retain their half of the north with the forest on it, then when the Government wishes to sell its timber the men who cut it will have to cross over private lands.

Mr. RAKER. As a matter of fact, in the northern part all the good land is owned by the Government, that is agricultural haml, areorrliner 
to the plat, and the timber land they have is scattered all over, so that they may put a sawmill in?

Mr. PicketT. I couldn't discover which land on the north the company owned.

Iir. ThwLEY. I think that is the case, the land in the southern half is principally raluable for agricultural purposes when irrigated, and in the northern half, more valuable for its timber, speaking generally.

Mr. Raker. And the Government lands seem to be of the pine character, so as to be suitable for irrigation. If that is a fact, that is just in an ideal condition for the (rovernment wo irrigate it and then sell ofl this little timber land to the rarious homesteaders for improvement, and such as that, and if they put a railroad in there, why of course, that would make it a very ideal condition to sell it.

Mr. Picketr. Is it not true that a railroad has already been projected and will be built through the center of this piece of land?

Mr. HAwLEY. It will be rather in the eastern side of the tract.

Mr. Raker. Does that railroad come near the little town of Quaker there?

Mr. MAWrer. I couldn't say, Judge. In answer to your statement, if there are any of the lands in the north that are level, and I think there are some now covered with valuable timber, if no exchange is made the company intends to irrigate those lands and remore the timber, so that what is now a solid body of timber in the north would become one on which the alternate sections would be irrigated, and it will be very diffieult to get the Government timber out over the irrigated lands without doing a great deal of damage to them.

Mr. Pickett. I suppose you would favor such plan as would open up the greatest number of acres to settlers?

Mr. HAWLEY. That is the desire.

Mr. Pickett. And if they derised a plan to open it up it would bo agreeable to you?

Mr. Hawley. If it be such a plan as would be taken advantage of and put into effect.

Mr. Mondell. That would be placed under the Carey Act?

Mr. Hawley. You would have then two systems of main canals, two systems of drainage. I think it would be a source of continual trouble to the settlers, because under the Carey $\Lambda$ ct you would have even-numbered sections in one project and the odd-numbered in the other.

Mr. Moxienl. Under the Carey Act some private company would irrigate it then, and if this company is engaged in the business of building irrigation canals the same canal would do for all the lands, wouldn't it?

Mr. Hawley. I can not speak for the company, but I suppose it might possibly agree to do that if it could make a reasonable charge for the water service to the Government lands. If the company is to build canals to irrigate its present holdings it will have to be done within the coming month, before its rights expire.

Mr. Raiser. What do you think, as a matter of public policy solely now, of the advisability of reserving this land north of Coral Springs, or, in other words, the north half of the township, since the railroad is going through that country and there is, from all observations from the statement made from the letters from the company, sufficient 
water fy huilding some dams and holding the water hack in thone lakes to irrigate these lands?

Mr. MAwLEY. The letter says they have water enongh to irrigate the land they own. I conldn't answer further than that, whether their engineer found water enough to irrigate all of the tract or not.

Mr. RAner. Since the railond is projected through these lands, would it not be better to permit all this land to be obtained from the Government by homesteaders or desert-land (daimes than it would be to let it in the forest?

Mr. In w wey. I don't see that there would be any dillerence under the proposed bill. The area of land which ran loe selted upon will not be decreased but lather increased by the exchange, and I was looking for the prospect of an immediate development. I don't sea any prospect for the derelopment of that commtry lor a comsideralyle length of time to come outside of the present project. I want to say that I have no personal interest in this matter. I never sam these gentlemen until about a month ago when they (ame and talked to me about the matter. I think it. would be a good exchange on the part of the Government, and I know it would be a good thine for that section if a system of irrigation would be introduced to inigate the land.

Mr. RAFer. That was 10 year ago or 15 years ago worthless, (ven in places where they have obtained title sinces, and s years agro it was considered to be worthless, by virtue of the gond limd being talien where there is water, we find where men have taken their money and developed a water system, gone bark into the mountains and jut in reservoirs, that the land that was considered worthless with water on it to-day is just as valuable as the good land, and just heca?use it had a water-right clause to it from the hills, and with the railroad going through that country, of course that is beginning to derelop it to where it nerer was before, rou find that to be the condition, don't you?

Mr. Hawler. Yes, that country is filling up in the southeris palt under the Goremment reclamation project. But if the proposer project is completed with the water rights that they would have and with the cimals they intend to huild, it would be rorre difficult to induce amybody to go in there and parallel those ('anuls and it would be diffeult to settle the question of damage from drainage and other matters.

Mr. Raker. Wouldn't it be more advantareous to the Govermment if those people went on with their inrigation project and said to the Govermment, "Well, if you will throw this land open to actual settlers, homesteaders, or ilesert land claimers, hut suppose they are homesteaders, we will agree with them on the water light, the same as we do with our own land," you should hare the land all settled inside of a year, then you would find every foot of this land in the south there open to settler's, and rou would find the land in the north, which rour letter shows could be irrigated, inside of a month rou would find it all open and you would find Goremment sections all applied for ready for actual settlers.

Mr. SpeEr. Is it adrisable that these lands be kept as a permanent United States forest reserve or that they eventually be disposed of ?

Mr. Potter. We are perfectly willing to recommend the opening of the lands for settlement but nohody wants them without water, so 


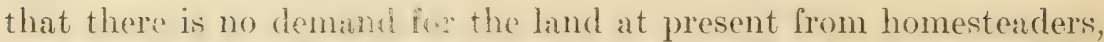
because there isn't wny way in which agricultural crops could be raised on them.

Mr. RAKER. The only trouble in this matter is that this land is below the water supply acom ding to the topographical map here.

Mr. Fengtisox. That doesn't make any difference if it is necessary to drain the water down to preserve the source of the water by preserving the timber.

Mr. Raker. If the timber is below the water supply and below the lakes, it certainly don't retain the water that makes the lakes and the streams below

Mr. Ferguson. Is that a fact?

Mr. RAKER. I judge so according to the map.

Mr. SPEER. If this company should nuke an applieation to the Land Department, the Forestry Department, and the Secretary of the Interior, and put the necessarv documents and records on file that they would permit the homestead claimants or the desert-land claimants to participate in this water there, don't you believe that the Government would sed this land opened immediately by settlers or that such an arrangement could be made for settlers?

Mr. PotTer. Tes, sure. We would recommend favorably on applications for listing the land if there was an irrigation system by which the land could be irrigated.

Mr. Speer. Then you don't seem to think that these lands are suitable to be kept for permanent forest reserves?

Mr. Hawley. Not the land in the lower half. The theory is now that we ought to acquire the western portion for forest reserves.

The ('mammax. The clerk of the committee telephoned to the department yesterday. They informed us they have absolutely no information about it. They sile-step this question entirely. Now, we haven't got sufficient information as to values to enable us to act intelligently. I doubt if there is a gentleman on this committee who would think for a moment of exchanging this land, under the circumstances, if it were his own, and I suppose we ought to look at the question as if it were our own, and it seems to me that there should be hearings on this matter and that we should have sworn statements printed to protect us in the action we would take in this matter as to values, as to water rights, and as to other conditions affecting this exchange, and it does seem to me as if we are not in a position to take action in this matter at this time. If the majority of the committee are of that opinion, I think we are wasting time discussing it further now.

Mr. Pickett. I am of the opinion that we are not sufficiently advised.

The Criminan. The way to be advised, I think, would be to refer the matter to a subcommittee with authority to take testimony or have the witnesses come before the whole committee and have a reporter here to make a reprort and have something to protect us if we made a favorable report.

Mr. Lafferty. While $\mathbb{I}$ am in no way interested myself in this matter, these three young men come to me highly recommended. The land is in Mr. Hawley's district, and that is why we are both here. It seems to me that the trouble that has overtaken this discussion is this fact: While sume member of the committee suggested 
informally when we came in this morning that the trouble was lack of information, I observed that the trouble was too much information. If this bill or discussion of it had been confined to the simple question involved whether or not this was a good exchange, if the simple proposition had been put up to the committee whether or not the Forestry Department would be authorized, or the Interior Department would be authorized on recommendation of the Forestry Department, to exchange certain desert lands for certain lands to the north, of a greater value for forestry purposes, thereby solidifying the facts, it would have gone through this committee and through the House without any objection, as numerous other bills did during the Sixtyfirst Congress; but these three young men came from Portland and thought they were strengthening their case by explaining their project to the committee and left the papers with Mr. In wley to present them to the committee. If the question of the feasibility of different irrigation projects had been left entirely out of the question, there would have been no trouble here. However, I think it is rery well to have brought the matter up; I have profited myself by these discussions here as to what ought to be done with other lands to the north that are adjacent to the forest reserve. We have over $16,(000,000$ acres of land in the forest reserves, more than one-fourth of the State, not paying any taxes. The people of Oregon are friendly to the Forestry Serrice; but there are millions of acres of desert land without a tree on it in the forest reserres in Oregon that ought to be opened up to homestead settlers. I think the Government is getting the best of the trade. Whether they go ahead and irrigate it or not: the Government is getting the best of the trade. It would hardly be practical for this committee or Congress to go into the question of clisposing of various lands in this bill; but I am glad that the discussion has taken the wide range that it has, because I feel we all got some benefit out of it.

The CHomrus. If you will pardon me, I don't deny anything you have said. Sustantially rou tell us that the Government is gettinge the best of the trade. While rou are probahly right, do you think the committee would be justified in accepting that statenent from you and acting on your statement?

Mr. IAFFERTY. I think if we can not aecept the statement of the Forestry Department, we are absolutely helpless.

The Cmamax. No; it isn't the cluty of the committee or Congress to accept the statement of any of the departments as an absolute fact.

Mr. Lafferty. I have been in this comntry myself and I know that this land is worthless in its present condition. A man can take a tree 3 or 4 years old and pull it up by its roots.

The Cmammax. If we had these facts in the form of evilence, we could tum them in with our report or refer to them, and then we would stand on better ground; but if we went on the floor of the House to defend this measure and told them there that Mr. Lafferty was interested in this deal, and that Mr. Hawley was interested in this deal, and told us so and so, do you think they would accept that?

Mr. LAfFerty. I think they would. I don't want the committee to understand that I am trying to hurry the matter, if a further consideration will result in opening up lands. 
Mr. Speer. The purpose of the Government keeping forest lands is to keep them reforested permanently.

Mr. LAFFenty. This is a condition well known to everybody familiar with forestry matters, and you can preserve those forests of Oregon as long as this world shall last, and at the same time you will be able to furnish sufficient timber from our forests for all the needs of this country and have some for export. I don't think there is any doubt about it.

Mr. HawLEY. The Government would not be any better off if they grew forests on ground they now own than they would to exchange that now in a barren condition for lands that already have good timber. The Government, if it grew good trees, would have no more trees 300 years from now than they would have to-day if they made the exchange.

Mr. LAFFerty. Mr. Chairman, I have traveled through central Oregon in my campaign last fall-three-fourths of the State is in my district-and I went all over it in an automobile, and I rode through several townships in forest reserves where there wasn't a tree in sight.

Mr. Hawley. It is my desire to assist the committee in getting any information it desires, and will be glad to help it in every way possible; but there is this thing confronting us at this time-the water rights expire on the 1st of April; that is just 32 days from to-day, including to-day. The company must make a substantial beginming before that time with the work, and they must begin within a few days.

Mr. TAYLok. What water rights have they got if they haven't made a filing in the office of the Secretary of the Interior?

Mr. HAwLEY. They have the water rights under filings made with the State engineer of Oregon. There is no loubt in the world but what they have the legal water right. It will take 10 days to get representatives of the company here.

Mr. TAYLOR. Is there no way to refile that?

Mr. IIAwLEY. I think not, if you gentlemen are satisfied that the exchange is a fair one to the Government. There had been a great deal of speculative matter that has been interesting, but it seems to me that is more speculative than of immediate value just now. It may become true and it may not. But if you think the exchange is fair and proper, it gires the Government a large tract of good timber land in exchange for valueless, practically valueless, barren land. It gives '24,000 acres to the company in a solid body. But if you can not see your way clear to accept the proposition, I would like to be able to inform the company who are waiting upon you in the matter, so that they can sare themselves. I hope you may see your way clear to report the bill.

Mr. LAFFERTY. I would be willing that an amendment be put into this bill, saying that the Forest Service shall not recommend this exchange vinless they find the lands that the company offers to relinquish are of a greater value.

Mr. Potter. In reference to the matters which Mr. Lafferty has referred to, I have to say for the information of the committee that during the past three years, as the result of careful examination, over $9,000,000$ acres of land have been eliminated from the national forests, and since the passage of the act of June 11, 1906, we have 
listed for settement 1,000,000 or more atres. In reforenee to this matter of land exchange, the Forest serviee, of contse, has!n't sufficient information about this particular land to say definitely just what exchange should be made.

The Cinaminax. What do you think of the suggestions made?

Mr. Potter. That is the reason why we reeommend general legislation. It may be that we would follow exactly the same plan in this exchange that has been followed under the Kansas bill passed at the last session of Congress, which was exactly the same in its provisions as this bill, or we might follow the plan adopted in the exchange of South Dakota lands with the State, which was to examine carefully each section of land and determine what its ralue was, taking into consideration all of the different factors. I brought with me this morning the papers in the South Dakota case, merely to show you the plan under which we made the exchange. In each section the examiner reported on three types, type 1, type 2, and type 3 of timberlands, and fixed the values for each of those types, then the amount of the young growth of trees as to whether it was very good, good, fair, or poor and what value should be placed on that; also the value of the bare land, without the trees, for agricultural purposes. We determined the value of each section on that hasis, and then found lands that on the same basis of value could be given to the State in exchange. I contemplated that in making any exchange of the land we would take the necessary steps to determine the exact value of the lands from these difierent standards and then ofier an exchange which would be absolutely fair to the Gorernment and give equal values.

Mr. PicketT. I would like to ask some gentleman here this question: If this bill does not go through, from which lake would the Oregon company take its water?

Mr. HawleY. They will take their water from fire lakes--(rescent, Odell, Summit, and Fish Lakes, and Big Marsh.

Mr. Piскетт. These lakes are in the northern portion of this land?

The Chamanax. And they will do that in case the consolidation is effected.

Mr. Picketr. Then they will run their main camals down throngh the center of this tract, I presume?

The Chamman. Yes, sir.

Mr. Pichett. Do I understand that under the laws of Oregon they can run their canals down through, for instance, several sections of land that is under private ownership and refuse to give them water?

Mr. Hawley. They must supply water to those with whom they may have made prior contracts first.

The Chamman. I suppose ther can condemn under the eminentdomain laws, same as they would for a railroad or public highways.

Mr. Picketr. Here they pass over a tract that they don't own and then again ther will go through a section which they do own or somebody else owns. Do I understand that under the laws of the State of Oregon that as to these sections which were sold to settlers that they absolutely could not get any water unless the company wanted to give it to them?

Mr. RaKer. Well, I have asked these gentlemen, and they have not explained it yet. I made a few observations but they differ with me; but being both attorneys from Oregon, I didn't feel like going into the record at this time as to my opinion of the matter. 
The Chamman. Let me make this suggestion: That either at this time or quickly hereafter, the bill be amended so as to secure from this company a waiver of all claims to the water rights from those lakes or streams north of the proposed consolidation before the consolidation of the bill goes into effect and is passed, and that we put in the bill a provision that the Agricultural Department shall carefully examine the ground and not make the exchange until it is satisfied that the Government is getting at least as much value as it is giving. Would the bill be a good one to pass if those two features were in?

Mr. HAwLEY. I would be willing to add a third, that they shall surrender all their holdings in the north for lands in the south.

The Cimammax. That would be embraced in the consolidation to draw a line, north of which the Government would govern all.

Mr. Volstead. It seems to me that it would be a better provision, if it is practicable, to irrigate the lands both in the north and the south and make such exchanges of lodge pole pine land for the yellowpine land as will give to them an opportunity to take the irrigable lands and turn them over to the settlers.

Mr. PotTer. It might, if the classification could be made solely on the agricultural value of the lands. I think it would be possible to reach an agreement in a general way.

Mr. Mondell. You take this map, and it seems to me it shows very clearly that there is a draft of this land in the north, as well as in the south, to give irrigation there, and also showing the land in the north that is owned by the Government and by this company. It serems to me we can consolidate the timber land and consolidate the low lands in separating the separate ownerships that we are contemplating by this change. ITe mar recuure that they should irrigate the whole of it; and in all probability there is plenty of water for both. That would make it a good deal better than the proposition that is suggested, that probably ties up the northern half of this country and probably leaves it where it never would be irrigated.

The Cimatrans. Let me raise another question on which we have not enough light, and that is how much water-that is, how much of that land that can furnish water to irrigate?

Mr. Mondell. It is perfectly evident that there is considerable, anyway, in this section.

The Cimmonas. You may have a big lake and mighty little water to irrigate the land. You see a lake may be fed by a comparatively small spring that will keep it up to a certain level, and not furnish much overflow. What is the flow anyway there? That is a question we have no light on.

Mr. Moxdel.L. I want every foot of this land that is really suitable for farmers and not for forests to be opened up if it can be done, and it seems we are trying to prevent it for a good many years, preventing the opening on the north half of that tract. That is one of the things which you should take into consideration.

The Chairsax. What immediate action do you propose by the committee?

Mr. Mondeld. The first thing we should do is to find out whether we have sufficient water supply up there, and if we have, I would suggest that we draft a bill so as to make the exchange with that 
purpose in riew so as to encourage the opening up of lands rather than discourage that.

Mr. Prcketт. I believe in opening up every foot of fertile or tillable land, but the point to this proposition is largely this: Here is this corporation that will get the land for practically nothing. Instead of doing as is done under the Carey Act, this company, in addition to the cost of construction, can add $\$ 50$ or more per acre and a few million dollars at the expense of the settlers. It seems to me that the Government if it opens it should do so equitably and fairly.

Mr. Mondell. We could do that in some such fashion as this: We could provide that they shouldn't get more than a certain amount above the expenses of irrigation.

Mr. Hawlex. The only objection is that we don't have that times.

Mr. LAFFERTY. I have information from the State engineer through Senator Bourne that these water rights will be extended, if this bill is passed during the present Congress; that the water rights filed will not be held forfeited on account of the failure of the company to begin work, but will be held open during the present session of Congress, I should have said, to sce whether or not this measure passes.

Mr. Hawlex. I had no such information. They told me that they had to begin operations before April 1, 1912.

Mr. Mondell. Can your State engineer tell how much water there is in that section?

Mr. LAFFERTY. I will wire him for the information. This company will have to borrow money no doubt to put in the work; it is going to be very expensive, and there is a hazard to it, and it is not going to be as valuable as lowlands where you can raise fruit. They are men of the highest character. I doubt if it might not prevent the building of their project if there are too many restrictions thrown around it. I am willing to have it referred to a subcommittee.

Mr. SpeEr. I move that it be referred to a subcommittee, of which I am not to be one, but I think Mr. Volstead ought to be on it, and that they be requested to report promptly.

Mr. Ferguson. Let me suggest that as it comes up now that I presume that motion ought to be referred to a subcommittee.

Mr. Speer. Then I move that it be referred to a subeommittee.

Mr. Pray. We have had such information as you have before the committee, and we felt satisfied that they were perfectly satisfied to have it referred to the Secretary of the Interior. Te were satisfied that it was a fair exchange.

The Champarax. Let me state Mr. Speer's motion, with some suggestion that comes to me: That the bill be recommitted to the subcommittee, with suggestions to that committee that it ascertain by evidence how much land can be irrigated by the water available; how much of the north part, which would fall to the Government, is adapted to agricultural purposes; to amend the bill calling for a waiver of the claims the company now has on the water toward the north end of this tract of land, and to further amend it, putting the burden on the Department of Agriculture to determine the comparative values before the exchange is made; and such other steps as occur to the subcommittee as relevant to this matter. 
Mr. Volstead. I would like to suggest this addition, that they take into consideration whether all of this land that is suitable for agricultural purposes can not be put under irrigation by making a suitable exchange both in the north and south.

Mr. Picietr. And that some superrisory control on the part of the Government be had as to the prices charged, etc.

Mr. Steer. I have been very much impressed with what has been said; that what we should keep is the land which would be available for forestry purposes in the near future and let the land that is suitable for agricultural purposes only go.

The Crmarman. I suppose that the company's land would lie to the south and the Government's land to the north.

Mr. PotTer. That would be my idea.

Mr. LAFFERTY. This subcommittee is composed of three members and only one of these has heard the discussion to-day. How would it he if the subcommittee be increased to five and two more members be designated by the chairman, who have heard this discussion, to meet with Mr. Pray in this matter?

Mr. Raker. In addition to this, before I can at least intelligently act, I want to know the kind and character of the improvements, and the kind and character of the business that they intend to engage in, whether it is to be a strictly private enterprise or whether it is for the purpose of disposing of all of this water for any purpose-agricultural, irrigating, power purposes, or whatever clse it might be.

The Chamman. What do you think of the suggestion?

Mr. Pray. I will say this. We had some difficulty in getting together. In the first place the members were very busy-Mr. Dent was busy, and Mrr. Estopinal and Mr. Ruby, and it seems to me that it would be a good idea to have a new subcommittee take hold of it. We have had the hearings. Mr. Hawley appeared before us, and also Mr. Lafferty, and we had the report from the Forester, and we were satisfied that if the bill was properly safeguarded it would be safe to leare it to the discretion of the Secretary of the Interior and the Secretury of Agriculture to make this change, because it had been done leretofore. I think it would be a good idea to appoint a new subcommittee.

The Cmammax. The Chair is not in sympathy with that subcommittee being reappointed. In the absence of any objection, the chair will take the liberty of adding two members to that committee. Is there any objection? The chair hears none, and we will add to that subcommittee Mr. Raker and Mr. Pickett.

Mr. RAKER. I would like to be excused from serving.

Mr. PraY. Well, if I am to be retained on that subcommittee, I will insist on Judge Raker being on it.

Mr. HAwleY. I would like to go on the record as saying that we applyeriate rery much the courtesy of the committee, and it has been a very remarkable exhibition of lindness and courtesy on your part.

The Cimarman. Mr. Speer's motion remains that the matter be referred to a subcommittee, with suggestions.

The committee thereupon adjourned. 



\section{LIBRARY OF CONGRESS

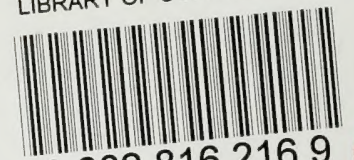 00028162169}

